\title{
ATTEMPTS TO CODIFY \\ THE INTERNATIONAL LAW OF PIRACY \\ WITHIN THE FRAMEWORK OF THE LEAGUE OF NATIONS
}

\author{
Zbigniew B. Rudnicki ${ }^{\star}$
}

The Assembly of the League of Nations, during its meeting on 22.9.1924, acting upon the proposal of the Swedish delegation, unanimously adopted a resolution requesting the Council of the League to set up a committee of experts ${ }^{1}$ consisting of the representatives of contemporary civilizations and the major legal systems of the world. This committee was to be charged inter alia with the duty to draw up a provisional catalogue of the international law subject matters whose codification by way of international agreement would be the most desirable and feasible at that time, and to report to the Council on the questions which were sufficiently ripe and on the procedure which might be followed with a view to finally preparing for conferences for their resolution ${ }^{2}$.

* University of the Cardinal Stefan Wyszyński in Warsaw.

1 "The Committee was at special pains to confine its enquiry to problems which it thought could be solved by means of encountering any obstacles of a political nature". S. Rosenne, The League of Nations Committee of Experts for the Progressive Codification of International Law (1925-1928), Oceana, Dobbs Ferry, N.Y. 1972, Vol. II, at p. 33.

2 'The American Journal of International Law' 1926, Vol. 20, Special Supplement 2-3. 
Accordingly, such a committee of experts was appointed by the Council of the League of Nations at its $32^{\text {nd }}$ session in Rome in December 1924. ${ }^{3}$ Following the second meeting in Geneva (12-29.1.1926), the Committee, via the Secretary-General of the League, sent to the governments of the states, whether League members or not, communications embodying a provisional list of the subjects of international law, the regulation of which by an international agreement appeared to the committee to be the most desirable and feasible at that time. These subjects listed were as follows: (1) nationality, (2) territorial waters, (3) diplomatic privileges and immunities, (4) the responsibility of states in respect of injuries caused in their territory to the person or property of foreigners, (5) the procedure of international conferences and the procedure for the conclusion and drafting of treaties, (6) piracy, and (7) exploitation of the products of the sea.

Most of the replies from some thirty governments, including the United States, submitted to the Committee of Experts at its $3^{\text {rd }}$ annual session, held in Geneva between 22.3.1927 and 2.4.1927, were encouraging to the Committee's view concerning the desirability and feasibility of a temporary agreement on the aforementioned subjectmatters. At the same session, the Committee decided to recommend to the governments that the following supplementary subjects were also ripe for international settlement: (1) the communication of judicial and extra-judicial acts and Letters Rogatory in criminal matters; (2) the legal position and functions of consuls; (3) revision of the classification of diplomatic agents, and (4) the jurisdiction of courts over foreign states.

At the $8^{\text {th }}$ regular session of the Assembly of the League of Nations in September 1927, to which the subject had been referred by the $45^{\text {th }}$ session of the Council in the preceding June, the work of the Committee of Experts of the League was examined, and the Assembly decided

3 The Assembly of the League of Nations formally requested the Council of the League to prepare a provisional list of subjects of international law the regulation of which would seem to be most desirable and realizable. The Committee responsible for compiling this list included piracy and also the Draft Provision for the Suppression of Piracy, but these were removed from the conference agenda on the grounds that piracy was no longer a pressing issue for the international community and that realization of a universal agreement seemed somewhat unlikely at that time. 
to summon the Codification Conference and firstly, to arrange for its preparation and convocation (it was considered that such a conference might be held in 1929 in The Hague), secondly, to request the Committee of Experts to complete its work, and thirdly, to submit for examination by the conference three key questions concerning: nationality, territorial waters, and the responsibility of States for injuries caused in their territory to the persons or property of foreigners.

The focus of attention in this paper - piracy - was amongst the subjects selected by the Committee of Experts for the Progressive Codification of International Law, established under the aforementioned operational plan. A sub-committee composed of M. Matsuda of Japan, acting as rapporteur, and $\mathrm{M}$. Wang Chung-Hui of China delivered the Report to the Committee in January 1926. The final Report, as amended by M. Matsuda on 26.1.1926, was submitted as the results of the Committee's works ${ }^{4}$ and distributed to governments for their attention and comments on 29.1.1926.

This Report made no reference to learned texts or specific cases or state practice, so there is no distinction between these elements that might be useful to codify well-based existing international law and those that might be novel. The main statement of the Report was that there was a significant "confusion of opinions" amongst scientific authorities on the subject of "piracy" but that such confusion had not arisen by virtue of doctrinal differences or the changing perceptions of states over time, nor because of any other reasons of differing opinion. It was approved in spite of "the failure to draw a clear distinction between piracy in the strict sense of the word, as defined by international law, and piracy coming under the private laws and treaties of individual states" 5 .

Consequently, the eight items mirrored in the articles of the Draft Provisions for the Suppression of Piracy proposed by the Committee and drafted in its final form by M. Matsuda on 26.1.1926 were based on the assumption that there is a single conception of "piracy" in the

4 M. Wang was unable to attend the Committee's meeting and the amendments were made in the Committee by M. Matsuda without his concurrence. League of Nations, Committee of Experts for the Progressive Codification of International Law: Reports, Geneva 1926, at p. 222 note 2.

5 Ibidem at p. 228. 
international legal order, reflecting a stable natural law that has not altered with the passage of time ${ }^{6}$.

The responses of governments to which the Report was circulated were very detailed and serious questions were raised as regards each of the draft articles ${ }^{7}$. Only one state, Portugal, commented on the usage of the word "piracy" in the light of historical sources. The Portuguese document states that "the Norman pirates acted on the western coasts of Europe, and later the pirates in the Mediterranean attacked settlements on the sea-shore; did not limit their piratical activities to the "high seas'"8. Despite this, the Matsuda's Committee of Experts' definition did not represent a codification of the entire body of customary international law relating to "piracy", nor did it offer any deeper analysis. No significant discussion of the universality principle contained in Article 7 took place. There was no clarification available as to whether the second paragraphs of Articles 4 and 5 were added with the naval incident of Pacocha in mind (1877) ${ }^{9}$.

The avoidance of problems of historical and legal analysis which the Committee and its Rapporteur seemed reluctant to attempt to resolve, or unable to resolve in light of the strong jurisprudential assertions and policy positions of many states, resulted in the draft being presented without any historical or legal analysis, as a proposal for new law regardless of history and theory. This was permissible to the extent that "progressive" codification within the competences of the Committee, and amendment of prior legal concepts were inevitable and unavoidable in any codification. Accordingly, given the progressive outlook of the proposal, its lack of conformity with history and theory was deemed unimportant ${ }^{10}$.

6 See: Appendix 1.

7 The replies are set out in their entirety in the League of Nations.

8 The Portuguese comment is conveniently reproduced verbatim in the Analysis of Replies submitted to the Committee of Experts by M. Matsuda and reprinted in "The American Journal of International Law' 1928, Vol. 22, No. 1, Supplement: Codification of International Law, at pp. 29-31.

9 Supra note 4, in particular at notes IV-292.

10 Cf. H. Lauterpacht, Codification and Development of International Law, 'The American Journal of International Law' 1955, Vol. 49, No. 1, at p. 16. The Committee's likely logic is in fact spurious. Codification proposals that are not well-founded in history and theory quickly tend to become legislative sessions in which each participant seeks to maximize his benefits in disregard of "progressive development." Cf. R. Baxter, Treaties and Custom, 'Recueil des Cours' 1970, Vol. 129, at p. 25. 
Nevertheless, this orientation raised questions concerning the utility of the Committee's work on "piracy." In spite of the continued use of the same word in certain political and municipal law contexts, it was clear that "piracy" was no longer considered a very important issue in international affairs.

As the Polish Representative, Minister A. Zaleski, stated in his speech at the Council of the League of Nations on 13.6.1927:

"It is perhaps doubtful whether the question of Piracy is of sufficient real interest in the present state of the world to justify its inclusion in the programme of the conference, if the scope of the conference ought to be cut down. The subject is in any case not one of vital interest for every State, or one the treatment of which can be regarded as in any way urgent, and the replies of certain Governments with regard to it indicate that there are difficulties in the way of concluding a universal agreement" ${ }^{\prime 1}$.

His point of view was shared by N. Politis, the Rapporteur for a Sub-Committee of the First Committee of the Assembly of the League of Nations, who noted with regard to "piracy" that it is one of two subjects (together with diplomatic immunities and privileges) "on which the conclusion of a universal agreement seems somewhat difficult at the present time". He also stated that neither of these subjects "is important enough to warrant its insertion in the agenda of the proposed Conference"12.

11 League of Nations doc. C.254.1927.V, reproduced in 'The American Journal of International Law' 1928, Vol. 22, Special Supplement, at p. 222. The Conference mentioned by A. Zaleski was held in 1930 at The Hague as the First Conference for the Progressive Codification of International Law. It was regarded as a failure when it proved unable to produce any treaties that states would ratify. See J.L. Brierly, The basis of obligation in international law, and other papers, Clarendon Press, Oxford 1958, at p. 341. In fact the 1930 Conference produced a Convention on Certain Questions Relating to the Conflict of Nationality Laws; a Protocol relating to Military Obligations in Certain Cases of Double Nationality; a Protocol relating to a Certain Case of Statelessness; and a Special Protocol concerning Statelessness, all dated 12.4.1930. It failed to produce agreement on the width of territorial waters. A Second Codification Conference was proposed but never held.

12 'The American Journal of International Law' 1928, Vol. 22, No. 1, Supplement: Codification of International Law, at p. 346. 
The Assembly, in its Resolution of 27.9.1927, requested that the Council refrain from including "piracy" in the planned agenda for the Codification Conference ${ }^{13}$, and nothing more came of M. Matsuda's Report, nor the documentation it inspired.

The League of Nations plan of intended activities, preparatory to what was expected to be a major codification effort, prompted the faculty of the Harvard Law School to organize its own research effort to contribute to the Codification Conference. A Committee was set up by the Harvard Research program to consider the international law of "piracy" independently of the efforts of M. Matsuda and his collaborators in the League ${ }^{14}$.

The work of the aforementioned Committee resulted in a full draft Convention comprising 19 articles, albeit the final article was unrelated to "piracy" and de lege ferenda and instead concerned the peaceful settlement of disputes arising from the interpretation or application of the Convention, requiring that such disputes be referred to adjudication by the Permanent Court of International Justice or the arbitration procedures laid down in the second Hague Convention for the Pacific Settlement of International Disputes (1907).

The draft Convention reflected formulations de lege ferenda without violating the fundamental conception of the main function of the codification efforts as an aid to the attempts of the time to conventionalize the rules of international law as they ought to be, rather than as they could be, by examining theory and past practice ${ }^{15}$.

The draftsmen of the Convention on piracy faced difficulties with the appropriate scheme of the document and were required to decide on the subject and plan of this draft. The most important issue laid in finding the answer to the following fundamental question: how significant is piracy as a concept in the law of nations? Whilst seeking the answer, they were

13 League of Nations Official Journal, Spec. Supp. No. 53, Oct. 1927, at p. 9; reproduced in 'The American Journal of International Law' 1928, Vol. 22, Special Supplement, at p. 231.

14 Professor J. W. Bingham of Stanford University, who chose as his advisers a learned body composed almost exclusively of residents of California, became the Reporter of the Committee.

15 Draft Convention on Piracy, 'American Journal of International Law' 1932, Supplement, Vol. 26, at p. 743-747; see: Apendix 2. 
obliged to take into account the widely diverse opinions they encountered. As indicated in the introduction to the draft convention:

"This diversity is especially remarkable with respect to the following fundamental matters: (1) The definition of piracy in the sense of the law of nations; (2) The meaning and justification of the traditional assertions that piracy is an offence or a crime against the law of nations; (3) The common jurisdiction of all states to prosecute and punish pirates" ${ }^{\prime 16}$.

The group working on the draft Convention was comprised of prominent scholars in the field of international law. Nevertheless, weaknesses in the draft were immediately apparent. As to the substance of the offence, its authors used terms such as "rape", "wound", "enslave" and "imprison" interchangeably in the text without any explanation as to their intentions for doing so and no illustrations to justify the inclusion of such terms ${ }^{17}$. Participation the slave trade was explicitly excluded from the European definitions, since this type of transaction represented an important aspect of international trade ${ }^{18}$. Moreover, if "rape", "wound" and "imprison" should be included only because they constituted severe and violent offences, why were "torture" or even "assault" absent?

Furthermore, there was a lack of clarity as regards the distinction drawn between acts "committed in a place not within the territorial jurisdiction of any state" for the purpose of defining the offence, and an act otherwise within the definition (more broadly stated in Article 4 to include "any similar act within the territory of a state by descent from the high sea" for the purpose of defining a "pirate ship"). The definition of what amounted to "piracy" in article three includes an implied definition of who is a "pirate" (someone who commits an act defined as "piracy", such as any of the doubtful connections defined in paragraphs 2 and 3 of that Article). Article 4 contains a very broad definition of a "pirate ship". One could even

16 Ibidem, at p. 749.

17 The English common law offence of "robbery" had become the basis of the municipal law maritime offence which came to be known as "piracy" in England and America since adoption of the jurisdictional statute of 1536; and "kill" could be conceived to have acquired definitional clarity in practice.

18 B. H. Dubner, The law of international sea piracy, Nijhoff Publ., The Hague 1980, at pp. 134-135. 
think that a pirate ship with no pirates on board, or a pirate ship that had never been involved in the commission of an act of piracy fell within this definition provided that all of its attacks were raids conducted on the seashore. One could assume that it made sense to establish a category for ships not completely lacking nationality, from which an act of piracy could be committed pursuant to the definition provided in Article 3 of the Draft Convention. And why, if the attacking ship was identified as sailing under a national flag, should the law of piracy come into play at all? Finally, it is not clear why a ship which had been involved in attacks on the sea-coast should be regarded as a base for acts of piracy on the high seas whereas an identical ship which had not previously committed shore attacks would not be considered as a base for pirate raids on the high sea unless it had previously lost its nationality. Furthermore, if any vessel had first lost its nationality it would seem to be within the definition of a base for piratical acts at sea, regardless of whether or not it had first been involved in shore raids. Article 4 seems irrelevant to this extent.

As regards jurisdiction, territorial jurisdiction is undoubtedly the dominant approach and, contrary to the British government's decision to support the actions of Admiral de Horsey in the Pacocha naval incident $(1877)^{19}$, the pursuit into the territorial waters of any state is forbidden by Article 7. The language of the project shifts the responsibility on a coastal State to prohibit the pursuit, rather than precluding the authority of the policing state from pursuing the "pirate", but that seems to be as far as the drafters were willing to accommodate the British position in theory ${ }^{20}$. Moreover, Article 9 even seems to limit that concession by providing not only that any persons and/or property seized shall be returned to their territorial sovereign but also that compensation shall be payable.

Article 13 concerning universal jurisdiction cross-refers to the legality of the capture to determine whether or not the seizing state may apply its own law to the arrested property. If the capture was "lawful," such application is permitted even if there is no evident national interest in the incident beyond the fact of the seizure by its officials. Article 6 appears to legalize the distrainment of a pirate ship or a ship taken by

19 W. B. Rowbotham, The "Huascar" Incident, 'RUSI Journal' 1960, Vol. 105, No. 618; A.P. Rubin, The Law of Piracy, Newport 1988, at pp. 260-261.

20 Ibidem, at p. 220. 
piracy and possessed by pirates, and any property relating thereto; but the same capture of the same vessel and property would appear to be unlawful if the ship had only been used for plunder "against ships or the territory subject to the jurisdiction of the state to which the ship belongs" (Article 4). In the latter case, the ship would be ineligible for classification as a "pirate ship" and the question as to whether or not owners of the ship were "pirates" could not be settled until after the capture; the capture itself could not be considered to be "lawful" when completed. If the ship was not initially "taken by piracy" but had been lawfully purchased, or even taken by raid under the law of some territorial state whilst not on the high seas and not by sudden attack from the high sea, it is unclear whether any taking by another state's representatives would be "lawful" within the meaning of Article 6. Thus, if Article 6 does not render capture of the ship "lawful", Article 13 would appear to be inapplicable. It is apparent that the articles of the draft Convention do not constitute a clear provision for universal jurisdiction over ships and material goods involved in "piracy". This cautious treatment of ships and property suspected of "piracy" is particularly noteworthy, since it demonstrates a complete denial of the concept of a universal law of nations in the sense spoken of in the American Constitution; concepts incorporating the entire law of the sea within the law of nations and treating as irrelevant, from a legal perspective, the place or the sovereign authority of the tribunal established to apply such universal law in practice.

Article 14 seems to be an attempt to change that situation as regards criminal trials, but again the universality of jurisdiction is made conditional on the "lawfulness" of the "custody;" and such "lawfulness" seems dependent upon the interpretation given to Article 6. In the researchers' commentary to Article 6, no clue is given as to the complications involved; they seem to have considered that Article 6 merely codified an ancient "right of any state to capture on the high sea a foreign ship which has committed piracy or is the booty of pirates"

Many other questions and ambiguities are raised by the $1932 \mathrm{draft}$ Convention on Piracy but, since it was presented as a project de lege ferenda and was not in fact adopted as such, further analysis of these issues seems unnecessary for the purposes of this paper.

21 Supra note 15 , at p. 832. 


\section{Appendix 1}

Draft Provisions for the Suppression of Piracy

\section{"Article 1}

Piracy occurs only on the high sea and consists in the commission for private ends of depredations upon property or acts of violence against persons.

It is not involved in the notion of piracy that the above-mentioned acts should be committed for the purpose of gain, but acts committed with a purely political object will not be regarded as constituting piracy.

Article 2

It is not involved in the notion of piracy that the ship should not have the right to fly a recognized flag, but in committing an act of piracy the pirate loses the protection of the State whose flag the ship flies.

Article 3

Only private ships can commit acts of piracy. Where a warship, after mutiny, cruises on its own account and commits acts of the kind mentioned in Article 1, it thereby loses it public character.

\section{Article 4}

Where, during a civil war, warships of insurgents who are not recognized as belligerents are regarded by the regular Government as pirates, third Powers are not thereby obliged to treat them as such.

Insurgents committing acts of the kind mentioned in Article 1 must be considered as pirates, unless such acts are inspired by purely political motives.

Article 5

If the crew of a ship has committed an act of piracy, every warship has the right to stop and capture the ship on the high sea.

On the condition that the affair shall be remitted for judgment to the competent authorities of the littoral State, a pursuit commenced on the high sea may be continued even within territorial waters unless the littoral State is in a position to continue such pursuit itself.

Article 6

Where suspicions of piracy exist, every warship, on the responsibility of its commander, has authority to ascertain the real character of the ship in question. If after examination the suspicions are proved to be 
unfounded, the captain of the suspected ship will be entitled to reparation or to an indemnity, as the case may be. If, on the contrary, the suspicions of piracy are confirmed, the commander of the warship may either proceed to try the pirates, if the arrest took place on the high sea, or deliver the accused to the competent authorities.

\section{Article 7}

Jurisdiction in piracy belongs to the State of the ship making the capture, except: (a) in the case of pursuit mentioned in Article 5(2); (b) in the case where the domestic legislation or an international convention otherwise decides.

Article 8

The consequences of capture, such as the validity of the prize, the right of recovery of the lawful owners, the reward of the captors, are governed by the law of the State to which jurisdiction belongs"22.

Appendix 2

Harvard Research Draft Convention:

\section{"Article 1}

As the terms are used in this convention:

1. The term "jurisdiction" means the jurisdiction of a state under international law as distinguished from municipal law.

2. The term "territorial jurisdiction" means the jurisdiction of a state under international law over its land, its territorial waters and the air above its land and territorial waters. The term does not include the jurisdiction of a state over its ships outside its territory.

3. The term "territorial sea" means that part of the sea which is included in the territorial waters of a state.

4. The term "high sea" means that part of the sea which is not included in the territorial waters of any state.

5. The term "ship" means any water craft or air craft of whatever size. Article 2

Every state has jurisdiction to prevent piracy and to seize and punish persons and to seize and dispose of property because of piracy. This jurisdiction is defined and limited by this convention.

22 Supra note 4, at pp. 228-229; League of Nations doc. C.196.M.70.1927.V, at p. 119. 


\section{Article 3}

Piracy is any of the following acts, committed in a place not within the territorial jurisdiction of any state:

1. Any act of violence or of depredation committed with intent to rob, rape, wound, enslave, imprison or kill a person or with intent to steal or destroy property, for private ends without bona fide purpose of asserting a claim of right, provided that the act is connected with an attack on or from the sea or in or from the air. If the act is connected with an attack which starts from on board ship, either that ship or another ship which is involved must be a pirate ship or a ship without national character.

2. Any act of voluntary participation in the operation of a ship with knowledge of facts which make it a pirate ship.

3. Any act of instigation or of intentional facilitation of an act described in paragraph 1 or paragraph 2 of this article.

Article 4

1. A ship is a pirate ship when it is devoted by the persons in dominant control to the purpose of committing an act described in the first sentence of paragraph 1 of Article 3, or to the purpose of committing any similar act within the territory of a state by descent from the high sea, provided in either case that the purposes of the persons in dominant control are not definitely limited to committing such acts against ships or territory subject to the jurisdiction of the state to which the ship belongs.

2. A ship does not cease to be a pirate ship after the commission of an act described in paragraph 1 of Article 3, or after the commission of any similar act within the territory of a state by descent from the high sea, as long as it continues under the same control.

Article 5

A ship may retain its national character although it has become a pirate ship. The retention or loss of national character is determined by the law of the state from which it was derived.

\section{Article 6}

In a place not within the territorial jurisdiction of another state, a state may seize a pirate ship or a ship taken by piracy and possessed by pirates, and things or persons on board.

\section{Article 7}

1. In a place within the territorial jurisdiction of another state, a state may not pursue or seize a pirate ship or a ship taken by piracy and 
possessed by pirates; except that if pursuit of such a ship is commenced by a state within its own territorial jurisdiction or in a place not within the territorial jurisdiction of any state, the pursuit may be continued into or over the territorial sea of another state and seizure may be made there, unless prohibited by the other state.

2. If a seizure is made within the territorial jurisdiction of another state in accordance with the provisions of paragraph 1 of this article, the state making the seizure shall give prompt notice to the other state, and shall tender possession of the ship and other things seized and the custody of persons seized.

3. If the tender provided for in paragraph 2 of this article is not accepted, the state making the seizure may proceed as if the seizure had been made on the high sea.

Article 8

If a pursuit is continued or a seizure is made within the territorial jurisdiction of another state in accordance with the provisions of paragraph 1 of Article 7, the state continuing the pursuit or making the seizure is liable to the other state for any damage done by the pursuing ship, other than damage done to the pirate ship or the ship possessed by pirates, or to persons and things on board.

Article 9

If a seizure because of piracy is made by a state in violation of the jurisdiction of another state, the state making the seizure shall, upon the demand of the other state, surrender or release the ship, things and persons seized, and shall make appropriate reparation.

Article 10

If a ship seized on suspicion of piracy outside the territorial jurisdiction of the state making the seizure, is neither a pirate ship nor a ship taken by piracy and possessed by pirates, and if the ship is not subject to seizure on other grounds, the state making the seizure shall be liable to the state to which the ship belongs for any damage caused by the seizure.

Article 11

1. In a place not within the territorial jurisdiction of any state, a foreign ship may be approached and on reasonable suspicion that it is a pirate ship or a ship taken by piracy and possessed by pirates, it may be stopped and questioned to ascertain its character. 
2. If the ship is neither a pirate ship nor a ship taken by piracy and possessed by pirates, and if it is not subject to such interference on other grounds, the state making the interference shall be liable to the state to which the ship belongs for any damage caused by the interference.

\section{Article 12}

A seizure because of piracy may be made only on behalf of a state, and only by a person who has been authorized to act on its behalf.

Article 13

1. A state, in accordance with its law, may dispose of ships and other property lawfully seized because of piracy.

2. The law of the state must conform to the following principles:

(a) The interests of innocent persons are not affected by the piratical possession or use of property, or by seizure because of such possession or use.

(b) Claimants of any interest in the property are entitled to a reasonable opportunity to prove their claims.

(c) A claimant who establishes the validity of his claim is entitled to receive the property or compensation therefore, subject to a fair charge for salvage and expenses of administration.

Article 14

1. A state which has lawful custody of a person suspected of piracy may prosecute and punish that person.

2. Subject to the provisions of this convention, the law of the state which exercises such jurisdiction defines the crime, governs the procedure and prescribes the penalty.

3. The law of the state must, however, assure protection to accused aliens as follows:

(a) The accused person must be given a fair trial before an impartial tribunal without unreasonable delay.

(b) The accused person must be given humane treatment during his confinement pending trial.

(c) No cruel and unusual punishment may be inflicted.

(d) No discrimination may be made against the nationals of any state.

4. A state may intercede diplomatically to assure this protection to one of its nationals who is accused in another state.

Article 15

A state may not prosecute an alien for an act of piracy for which he has been charged and convicted or acquitted in a prosecution in another state. 


\section{Article 16}

The provisions of this convention do not diminish a state's right under international law to take measures for the protection of its nationals, its ships and its commerce against interference on or over the high sea, when such measures are not based upon jurisdiction over piracy.

Article 17

1. The provisions of this convention shall supersede any inconsistent provisions relating to piracy in treaties in force among parties to this convention, except that such inconsistent provisions shall not be superseded in so far as they affect only the interests of the parties to such treaties inter se.

2. The provisions of this convention shall not prevent a party from entering into an agreement concerning piracy containing provisions inconsistent with this convention which affect only the interests of the parties to that agreement inter se.

Article 18

The parties to this convention agree to make every expedient use of their powers to prevent piracy, separately and in co-operation.

Article 19

1. If there should arise between the High Contracting Parties a dispute of any kind relating to the interpretation or application of the present convention, and if such dispute cannot be satisfactorily settled by diplomacy, it shall be settled in accordance with any applicable agreements in force between the parties to the dispute providing for the settlement of international disputes.

2. In case there is no such agreement in force between the parties to the dispute, the dispute shall be referred to arbitration or judicial settlement. In the absence of agreement on the choice of another tribunal, the dispute shall, at the request of any one of the parties to the dispute, be referred to the Permanent Court of International Justice, if all the parties to the dispute are parties to the Protocol of December 16, 1920, relating to the Statute of that Court; and if any of the parties to the dispute is not a party to the Protocol of December 16, 1920, to an arbitral tribunal constituted in accordance with the provisions of the Convention for the Pacific Settlement of International Disputes, signed at The Hague, October 18, 1907. 